IZA DP No. 113

Do Mandatory Pensions Decrease Household Savings? Evidence for the Netherlands

Rob Euwals

February 2000 


\title{
Do Mandatory Pensions Decrease Household Savings? Evidence for the Netherlands
}

\author{
Rob Euwals \\ CEPR and IZA, Bonn
}

\author{
Discussion Paper No. 113 \\ February 2000
}

\author{
IZA \\ P.O. Box 7240 \\ D-53072 Bonn \\ Germany \\ Tel.: +49-228-3894-0 \\ Fax: +49-228-3894-210 \\ Email: iza@iza.org
}

This Discussion Paper is issued within the framework of IZA's research area General Labor Economics. Any opinions expressed here are those of the author(s) and not those of the institute. Research disseminated by IZA may include views on policy, but the institute itself takes no institutional policy positions.

The Institute for the Study of Labor (IZA) in Bonn is a local and virtual international research center and a place of communication between science, politics and business. IZA is an independent, nonprofit limited liability company (Gesellschaft mit beschränkter Haftung) supported by the Deutsche Post AG. The center is associated with the University of Bonn and offers a stimulating research environment through its research networks, research support, and visitors and doctoral programs. IZA engages in (i) original and internationally competitive research in all fields of labor economics, (ii) development of policy concepts, and (iii) dissemination of research results and concepts to the interested public. The current research program deals with (1) mobility and flexibility of labor markets, (2) internationalization of labor markets and European integration, (3) the welfare state and labor markets, (4) labor markets in transition, (5) the future of work, (6) project evaluation and (7) general labor economics.

IZA Discussion Papers often represent preliminary work and are circulated to encourage discussion. Citation of such a paper should account for its provisional character. 


\section{ABSTRACT \\ Do Mandatory Pensions Decrease Household Savings? Evidence for the Netherlands}

The Dutch mandatory pension system consists of two parts: a public pay-as-you-go part that provides a minimum income to all Dutch inhabitants over age 64; and an occupation-specific capital-funded part that provides supplementary retirement income. The goal of this paper is to test for the effect of mandatory pensions on discretionary household savings. The data are drawn from the CentER Savings Survey, which consists of a representative and a highest-income-decile sample of Dutch households. The survey contains rich information on house-hold wealth, pension rights and savings attitudes. A result of the empirical analysis is that the impact of the public part of the Dutch pension system is not well identified. The occupational pensions have a significant negative impact on savings motives with respect to old age. Concerning the effect on household wealth, evidence is mixed. Only in the highestincome-decile sample there is evidence for a significantly negative impact of occupational pensions.

JEL Classification: C21, D91, H55

Keywords: Savings, pensions, life cycle hypothesis

Rob Euwals

IZA

P.O. Box 7240

53072 Bonn

Germany

Tel.: +49-228-3894-302

Fax: +49-228-3894-210

Email: euwals@iza.org

\footnotetext{
"I wish to thank two anonymous referees, Rob Alessie, Axel Börsch-Supan, Angelika Eymann, Bertrand Melenberg, Jan Nelissen, Reinhold Schnabel, Arthur van Soest, Joachim Winter, and the participants of seminars at IZA, Tilburg University and the University of Mannheim for valuable comments and helpful discussions. I gratefully acknowledge the TMR network Savings and Pensions for funding. I also gratefully acknowledge the University of Mannheim for their hospitality, and CentER, Tilburg University, for providing the data.
} 


\section{Introduction}

As today many countries have some form of social security and mandatory contractual savings for longevity and income risk at old age, the question whether these systems depress discretionary household savings is important. At the national level, for example, the funding of the system might have a substantial effect on the volume of national savings. At the household level a generous system might lead to over-annuitization. Despite a substantial empirical literature on the national and the household level, the question whether mandatory pensions depress household savings is still open. The empirical results vary from strong displacement effects (e.g. Feldstein and Pellechio (1979), Kotlikoff (1979), Feldstein (1980), and Bernheim (1987)) to modest or insignificant displacement effects (e.g. Munnel (1976), Diamond and Hausman (1983), and Graham (1987)).

So far most studies based on survey data concern the US, only few studies concern countries in the European Union. This is peculiar given the differences in the pension systems within the European Union and the discussions on the transformations of these systems in Germany and Italy, for instance. The differences between the EU member countries are significant: The United Kingdom and the Netherlands, for example, have a capital-funded pension system with a high accumulation of capital in independent pension funds. Germany, Italy, and France, on the other hand, have a pay-as-you-go system and a low accumulation of capital in independent pension funds (see e.g. table 3.1 of Davis (1995)). The differences might have a major impact on the economic development within the European Union, as the funding of mandatory pensions might affect national savings and capital markets. A simple comparison of the EU member countries shows that the relation between the funding of mandatory pensions and national savings is unclear: In the Netherlands gross national savings are high, whereas they are actually low in the United Kingdom (24.6 and 13.7 percent of nominal GDP in 1994 respectively, see the OECD Economic Outlook). There are studies on the determinants of savings based on international comparisons (see Feldstein (1980) and Graham (1987)), but none of them considers the impact of the funding of mandatory pensions. As the number of countries and years for which data are available is limited, conclusions that are based on international differences only are not very convincing. Furthermore, as certain differences between the pension systems of different countries are hard to capture in an international comparison, evidence based on survey data for different countries is necessary. 
To the author's knowledge, evidence for countries of the European Union based on survey data is available only for Italy and the Netherlands. Based on the Italian Survey of Household Income and Wealth, Jappelli (1995) finds significant displacement effects. He suggests that about one-fifth of the drop in the Italian savings rate in the 1970s and 1980s is explained by changes in the pension system. Based on the Dutch Socio-Economic Panel, Alessie, Kapteyn and Klijn (1997) find contradictory effects for the different parts of the Dutch pension system. While a full displacement by public pensions is consistent with their data, they conclude that this is less likely for occupational pensions.

Another argument for the importance of more evidence on the effect of mandatory pensions on household savings can be found in Feldstein and Pellechio (1979). In their seminal article, the authors claim that "it should go without saying that no single econometric study can ever be conclusive." Since a final answer seems difficult to give, one possibility is to produce new evidence by using new and better data. Then the results become less data specific, which in turn might lead to explanations about why conclusions differ that much. This paper adds to the literature by using the CentER Savings Survey, which is especially devised to study household savings. It contains detailed information on household wealth holdings and pension rights. Therefore these data are more suitable to study the effect of mandatory pensions on household savings than the Dutch Socio Economic Panel which is used by Alessie, Kapteyn and Klijn (1997).

Besides using the traditional approach of studying household wealth, which is used in the papers cited above, it is also important to search for new perspectives on savings behaviour and mandatory pensions. The CentER Savings Survey contains a lot of interesting information on attitudes and perceptions with respect to savings. This paper additionally explores data on savings motives. In particular, it analyses opinions on the importance of discretionary savings as a supplement to social security and occupational pensions. The empirical analysis of these data provides evidence on whether individuals have their pension rights in mind while making statements on such topics. However, this is not a comprehensive analysis of savings motives. We do not correct for substitution effects between savings motives because there are many different motives to save.

This paper considers savings behaviour of households where a man at the age of 40 to 64 is head or partner in the household. The income and pension rights of women are neglected for reasons explained in section 3. The remainder of this paper is organized as follows. Section 2 discusses the Dutch pension system and the way social security and pension rights 
affect household savings. Section 3 discusses the data extracted from the CentER Savings Survey. Section 4 gives the empirical results, and section 5 concludes.

\section{Social security, pension rights, and savings}

To measure the effect of mandatory pensions on household savings, one has to formulate a model for savings behaviour. Since it is important to incorporate the specific rules of the system under consideration, subsection 2.1 explains the Dutch social security and pension system. Next, subsection 2.2 formulates an empirical model that takes the specific features of the Dutch system into account. Finally, subsection 2.3 discusses the advantages and disadvantages of the empirical model.

\subsection{The Netherlands}

The Dutch pension system consists of two mandatory parts: a public social security part and a private occupation-specific part. The public part, the so-called AOW, is a pay-as-you-go system that guarantees a minimum income to Dutch inhabitants over age 64 . The net benefit level is derived from the official net minimum wage. For instance, for a couple with no other labour income the net benefit level is equal to the net minimum wage, while for a single person it is equal to 70 percent of the net minimum wage. In practice, however, the benefits are paid in gross terms and are subject to taxes. Gross benefit levels are derived from net benefit levels for households with certain 'standard' characteristics. The public pension system is financed by a payroll tax on income up to a certain level and is paid by all citizens below age 65 who have an income above a certain tax-free amount.

The private part of the Dutch pension system is capital-funded. It is supplementary to the public part and consists of several occupation-specific pension schemes. They are mandatory in the sense that upon request of a representative selection of trade unions and employer organizations in a particular sector the Ministry of Social Affairs and Employment can make a pension scheme compulsory for all firms in that sector. This enforcement was common practice during the last decades. Only in recent years the Ministry of Social Affairs and Employment has been using this rule in a more conservative way and partly liberalised it. But in the case of enforcement, a firm can only opt out if it establishes a company fund which offers benefits that are at least as generous as those provided by the pension scheme of the 
sector. The Witte Vlekken op Pensioengebied (the 'Uncovered Areas of the Occupational Pensions', 1997, table 4.1) shows that about 91 percent of dependent employees aged between 25 and 65 are covered by an occupational pension scheme. Only in the younger sectors of industry, relatively many sectors have no pension scheme and relatively many firms do not have a company fund. The rules of pension schemes are partly given by law and partly negotiated by collective bargaining at the sector or firm level, the so-called CAOs. Although each sector or large firm has its own pension scheme, they are not so different in practice. The Pensioenkaart van Nederland (the 'Pension map of the Netherlands', 1987, table 3.2) shows that of the non-civil servant male participants of a pension fund aged 16 to 64 more than 99 percent have a pension of the defined benefit type. About 75 percent of these pensions are defined on the basis of final pay, the remainder being a mix of fixed amounts and average or final pay. Civil servants are covered by their own pension fund, the so-called ABP, which gives pensions of the defined benefit type. Since there have been no major changes in the pension system in the last decades, the numbers above are applicable to our sample period.

Taking into account social security, the aspiration level of most pensions funds is a before-tax replacement rate of 70 percent for participants who collected the maximum number of contributed years. Due to incomplete careers and certain rigidities in the occupational pensions only few workers reach the maximum number of contributed years. This leads to lower replacement rates for certain groups of workers. On the other hand, social security guarantees a certain minimum income, leading to substantially higher replacement rates for low-wage earners. These two facts lead to considerable differences in replacement rates. The Pensioenkaart van Nederland (1987, table 4.2.2) estimates that about 37 percent of the noncivil servant male participants of a pension fund aged 16 to 64 will have a replacement rate lower than 60 percent, while about 32 percent will have a replacement rate larger than 70 percent. As Dutch citizens over age 65 do not contribute to the social security system, replacement rates at an after-tax base are higher than at a before-tax base.

The private part of the pension system contains an element that is not mandatory in the sense that it can be enforced by the Ministry of Social Affairs and Employment: the early retirement schemes. These are also negotiated in and enforced by collective bargaining. Therefore, the rules with respect to early retirement - like retirement ages and benefit levels are sector or firm specific. In the period under consideration the early retirement schemes are pay-as-you-go, financed by the workers in the specific sector. Only in recent years some sectors have been transforming their early retirement schemes to capital-funded schemes. 


\subsection{Model}

The currently most popular model of intertemporal choice to explain household behaviour is the life-cycle model. Although most of the authors cited in the introduction refer to this model, few actually derive their empirical model in an explicit way. A notable exception is Alessie, Kapteyn and Klijn (1997) who derive an explicit solution for household wealth accumulation. However, their approach also shows some of the discrepancies between theory and empirical practice. An important discrepancy is that their empirical analysis uses actuarially discounted pension rights, which is not consistent with their life-cycle model with known lifetime. Now the notion of lifetime uncertainty is some decades old (Yaari (1965)), explicit modelling for this is another matter. Solutions are complicated, and to the author's knowledge they have not been implemented explicitly in an empirical analysis so far. Although improving the theoretical foundations of the empirical model would be a substantial gain, this is beyond the scope of this paper. ${ }^{1}$

The empirical literature does not pay much attention to the exact formulation of the lifecycle model, as the prediction from it is straightforward: Mandatory pensions should depress household savings. This paper follows the methodology to test the hypothesis in a reducedform model. But since in the interpretation of the empirical results certain aspects of the lifecycle model play an important role, a stylised version of the model will be introduced.

In the following, the individual or household index will be suppressed. Define $t$ as the current period, and $\mathrm{T}$ as the terminal period (= lifetime). We assume that individuals optimise the expectation of an intertemporal utility function with respect to a consumption path $\left(c_{t}, . ., c_{T}\right)$. This consumption path has to satisfy an intertemporal budget constraint. For the moment, we assume lifetime $\mathrm{T}$ to be known, so that uncertainty only comes through the unknown future incomes $\left(\mathrm{y}_{\mathrm{t}+1}, \ldots, \mathrm{y}_{\mathrm{T}}\right)$. The intertemporal budget constraint:

(1) $\sum_{s=t}^{T}(1+r)^{t-s} c_{s}=A_{t}+y_{t}+\sum_{s=t+1}^{T}(1+r)^{t-s} y_{s}$

with $r$ the interest rate and $A_{t}$ total private wealth at the beginning of time $t$. Crucial in the analysis is the last part of the intertemporal budget constraint. This part contains, for instance,

\footnotetext{
${ }^{1}$ In the empirical analysis I also estimated the models of Alessie, Kapteyn and Klijn (1997). The results were disappointing; almost all variables were insignificant. The results are available upon request.
} 
the future pension incomes. For an individual who works at time $t$, the total expected future income depends on future wages $\mathrm{w}_{\mathrm{s}}$, the timing of early retirement $\mathrm{s}=\mathrm{R}$, early retirement benefits $b_{s}$, and social security $s_{s}$ and supplementary pension $p_{s}$ after official retirement at age 65. The incomes are defined in gross terms, and the function $\mathrm{y}_{\mathrm{s}}($.$) gives the corresponding net$ income. We decide to ignore taxes on capital income. The last part of the intertemporal budget constraint can be written as:

(2) $\sum_{s=t+1}^{T}(1+r)^{t-s} y_{s}=\sum_{s=t+1}^{R-1}(1+r)^{t-s} y_{s}\left(w_{s}\right)+\sum_{s=R}^{65-1}(1+r)^{t-s} y_{s}\left(b_{s}\right)+\sum_{s=65}^{T}(1+r)^{t-s} y_{s}\left(s s_{s}+p_{s}\right)$

In the current version of the model, retirement age $\mathrm{R}$ is assumed to be exogenous; we do not allow individuals to optimise their intertemporal utility with respect to this. Later in this section we discuss the consequences of this assumption and a sensitivity analysis is provided in the empirical analysis. Early retirement benefits in pension wealth are not included for reasons discussed later

As social security $\mathrm{ss}_{\mathrm{s}}$ and supplementary pension $\mathrm{p}_{\mathrm{s}}$ are taxed together, they are added before the calculation of the corresponding net income. To be able to measure the effect of social security and pension wealth separately, we assume that the individuals consider social security as a base income, and supplementary pensions as an additional income.

(3a) $\mathrm{SSW}_{\mathrm{t}}=\sum_{\mathrm{s}=65}^{\mathrm{T}}(1+\mathrm{r})^{\mathrm{t}-\mathrm{s}} \mathrm{y}_{\mathrm{s}}\left(\mathrm{ss}_{\mathrm{s}}\right)$

(3b) $\mathrm{PW}_{\mathrm{t}}=\sum_{\mathrm{s}=65}^{\mathrm{T}}(1+\mathrm{r})^{\mathrm{t}-\mathrm{s}}\left(\mathrm{y}_{\mathrm{s}}\left(\mathrm{ss}_{\mathrm{s}}+\mathrm{p}_{\mathrm{s}}\right)-\mathrm{y}_{\mathrm{s}}\left(\mathrm{ss}_{\mathrm{s}}\right)\right)$

Under certain additional assumptions (like for instance homothetic intertemporally additive preferences, quadratic utility and individual discount rate equal to interest rate) the model has a closed form solution (see Deaton (1992) and Browning and Lusardi (1994)). As I do not want to make additional assumptions, I take a reduced form approach. From the intertemporal budget constraint it is clear that private wealth $\mathrm{A}_{\mathrm{t}}$ and future incomes $\left(\mathrm{y}_{\mathrm{t}+1}, . ., \mathrm{y}_{\mathrm{T}}\right)$ are substitutes for each other. The reduced form model:

(4) $\mathrm{A}_{\mathrm{t}}=\mathrm{x}_{\mathrm{t}}^{\prime} \beta+\alpha_{1} \mathrm{yt}_{\mathrm{t}}+\alpha_{2} \mathrm{SSW}_{\mathrm{t}}+\alpha_{3} \mathrm{PW}_{\mathrm{t}}+\varepsilon_{\mathrm{t}}$ 
with $\mathrm{x}_{\mathrm{t}}$ a vector of demographic variables and taste shifters and $\varepsilon_{\mathrm{t}}$ an individual error term. To test whether mandatory pensions depress household savings, one has to test the hypothesis that the parameters $\alpha_{2}$ and $\alpha_{3}$ are equal to zero $\left(\mathrm{H}_{0}: \alpha_{2}=\alpha_{3}=0\right)$. The life-cycle model predicts that pension wealth should depress household savings so that the alternative hypothesis is that the parameters $\alpha_{2}$ and $\alpha_{3}$ are strictly negative. In the literature, several authors go further and take the life-cycle prediction of complete displacement as the null hypothesis $\left(\mathrm{H}_{0}: \alpha_{2}=\alpha_{3}=-1\right)$. The section on the empirical results will mention this test, but will not emphasize it.

\subsection{Interpretation}

The life-cycle model formulated in the previous subsection is stylised and contains several sources for potential biases. Gale (1995) and Alessie, Kapteyn and Klijn (1997) discuss the potential biases in detail. This subsection discusses how serious they are for the interpretation of the empirical analysis in this paper. A peculiar quality of the potential biases is that they are upward. This means that even when the parameters $\alpha_{2}$ and $\alpha_{3}$ are biased upward by one of these sources, significant negative estimates for these parameters can still be interpreted as a rejection of the null hypothesis that they are equal to zero $\left(\mathrm{H}_{0}: \alpha_{2}=\alpha_{3}=0\right)$. In other words, the parameter estimates give upper bounds for the true parameter values. Because displacement effects by social security and pension wealth will be represented by negative parameter estimates, the displacement effects will be underestimated by the reduced form analysis. The remainder of this section discusses the importance of the different sources for the biases.

Two of the sources for potential biases mentioned in the papers above are taken care of in the empirical analysis: Age is included among the explanatory variables, and pension wealth is measured net of taxes. Thus these two sources are no problem for the interpretation of the empirical results.

Two other sources for potential biases have to do with measurement problems; both household and pension wealth are difficult to measure. Of course this is also a problem for the empirical analysis in this study, but it is still less serious than for other studies due to the data. The CentER Savings Survey is specially devised to study savings behaviour, which means that household wealth and pension rights are measured with more accuracy than, for instance, in the Dutch Socio-Economic Panel used by Alessie, Kapteyn and Klijn (1997).

The next two sources cannot be taken care of in the empirical analysis. First, according to the life-cycle model the effect of social security and pension wealth should be estimated based 
on lifetime income, not on current income. Since no data on the earnings history of the individuals is available in the data, correction for lifetime income is not possible. Second, unobserved individual heterogeneity with respect to savings propensity leads to the fact that individuals who like to save a lot for old age might also choose to collect a lot of pension rights in the occupational pension system. This induces a positive correlation between discretionary household savings and pension wealth, leading to an upward bias for the parameter $\alpha_{3}$. Of course this only holds if individuals are really able to influence their pension rights in the occupational pension system. Several studies correct for unobserved individual heterogeneity by using panel data, and such data are not available for this study.

The two remaining sources of potential biases will be discussed in more detail, as the empirical analysis will include a sensitivity analysis with respect to these sources. The first one concerns lifetime uncertainty. When a man believes that he (or his wife) has a high life expectancy, then their household has an incentive to collect both a lot of household wealth and pension wealth. Like in the case of individual heterogeneity, this leads to a positive correlation between the discretionary household savings and pension wealth. Therefore, the parameter $\alpha_{3}$ will be biased upward.

The underlying life-cycle model formulated in the previous subsection assumes that lifetime $\mathrm{T}$ is known. In that case the valuation of the future pension incomes is straightforward: The individuals take the expectation with respect to the uncertain future incomes $\left(\mathrm{y}_{\mathrm{t}+1}, . ., \mathrm{y}_{\mathrm{T}}\right)$. This becomes more complicated if we allow for lifetime uncertainty. The problem is that the lifetime budget constraint formulated in equation (1) does not exist anymore. The common solution to this problem is to assume perfect annuity markets: The individuals will insure themselves against lifetime uncertainty by buying annuities. This means that the lifetime budget constraint holds in expectation and that valuation of the future pension incomes will be on an actuarial basis. Bernheim (1987) claims that the assumption of perfect annuity markets is too strong. He argues that simple discounting (ignoring lifetime uncertainty) is a better approximation for the valuation of future incomes than actuarial discounting. Here both methods of valuation are used to see how sensitive the empirical results.

The second source of potential bias that will be taken into account by a sensitivity analysis concerns early retirement. Several authors in the literature stress the point that mandatory pensions might induce individuals to retire early (see for instance Diamond and Hausman (1984) and Rust and Phelan (1997)). Unfortunately, the story on early retirement is complicated for the Netherlands. The early retirement schemes are not mandatory in the sense 
that they can be enforced by the Ministry of Social Affairs and Employment. There is little uniformity in the early retirement schemes for the different industries and firms. Furthermore, these schemes are independent of social security and occupational pension schemes. ${ }^{2}$ In equation (2) we expressed this by formulating a separate term for early retirement wealth. The discussion is split up in two parts: First, we discuss the impact of the Dutch pension system on early retirement. Then the impact of early retirement schemes is discussed.

The social security and occupational pension system might induce individuals to retire early in case they are over-annuitized by the system, and borrowing against future income is difficult. Under-annuitization is likely to have a smaller impact because it can partly be compensated by private wealth accumulation. So individuals with high pension rights need to save less for their retirement period after age 64, which is what we want to measure. But they might save to finance early retirement, so that the effect of mandatory pensions on savings will be less pronounced. This biases the parameters of interest upward. We will see that the social security and occupational pension system has almost no effect on discretionary household savings.

Although the social security and occupational pension system might have some impact on early retirement, it will be relatively small compared to the impact of early retirement schemes. Labour market participation of the elderly is notoriously low in the Netherlands, and several studies show strong incentive effects of early retirement schemes. A complication in early retirement behaviour in the Netherlands is the presence of non-negligible interactions with social insurances. Kerkhofs, Lindeboom and Theeuwes (1998) show that there are substantial substitution effects between the different escape-routes offered by early retirement schemes, disability schemes and (long-term) unemployment schemes. It is beyond the scope of this paper to take this into account, also because data on the early retirement options of the workers is not available in the CentER Savings Survey. In the empirical analysis, we assume individuals over age 60 to retire with certain given probabilities. A method to correct for the endogeneity of early retirement would be to use information on planned early retirement of individuals (see for instance Diamond and Hausman (1984) and Jappelli (1995)). The CentER Savings Survey contains planned retirement age, but only for a part of the sample. We will do a sensitivity analysis using these data.

\footnotetext{
${ }^{2}$ For instance, in the US early retirement leads to a downward correction of the pension benefit to make the system actuarially more fair. Only recently these kind of adjustments were introduced for some early retirement schemes in the Netherlands. But this is of little importance for our sample period.
} 


\section{Data}

The data for this study are drawn from the CentER Savings Survey which contains about 3000 households divided in two panels. One panel is designed to be a random sample of all Dutch households, while the other one is designed to be a random sample of households in the highest income decile (of households) in the Netherlands. For this study we use the waves of the years 1993, 1994 and 1995. We will only be able to analyse the household wealth holdings of 1994 because the waves 1993 and 1994 have to be combined to one wave and the wave of 1995 contains data on income of the year 1994. For more information on the CentER Savings Survey, see appendix A.

We analyse wealth holdings of households in which a man aged between 40 and 64 is head or partner in the household. Table 1 shows the numbers of observations for men in the age-group 40 to 64 for both panels. It is evident that the use of the wealth and income data reduces the number of observations substantially. An explanation for the item non-response on wealth is that the method of questioning might have been quite exhaustive for the participants. For the non-response on income a major explanation is that income is asked in the next year's wave on the basis of the income reported to the tax-authorities. Besides the traditional item non-response, we therefore also get missing data due to panel attrition. For more information on the CentER Savings Survey and on the retrieval of the data, see appendices $\mathrm{A}$ and $\mathrm{B}$.

Table 1: Selection criteria and number of observations (wave 94)

\begin{tabular}{|c|c|c|}
\hline Selection criteria & Representative Panel & High-Income Panel \\
\hline Step 1: Men $(40 \leq$ age $\leq 64)$ & 901 & 589 \\
\hline Step 2: +Spouse & 876 & 576 \\
\hline Step 3: +Wealth & 668 & 474 \\
\hline Step 4: +Income & 440 & 375 \\
\hline Step 5: +Other & 416 & 364 \\
\hline
\end{tabular}

Note: Step 1 selects all men who are head or partner, step 2 merges the married men to their spouses, step 3 merges the wealth data of both the men and their spouses, step 4 merges the income data of the men, and step 5 puts some additional criteria (concerning item non-response). In case of a couple in which the man is mostly involved with the financial administration of the household and the wealth of the spouse is unobserved, the wealth holdings of the spouse are ignored. 


\begin{tabular}{|c|c|c|c|c|}
\hline & \multicolumn{2}{|c|}{$\begin{array}{l}\text { Representative Panel } \\
\text { (416) }\end{array}$} & \multicolumn{2}{|c|}{$\begin{array}{l}\text { High-Income Panel } \\
\text { (364) }\end{array}$} \\
\hline & Mean & (s.e.) & Mean & (s.e.) \\
\hline \multicolumn{5}{|l|}{ Employed } \\
\hline \# observations & 291 & & 314 & \\
\hline Age & 47.8 & (5.9) & 47.4 & (5.4) \\
\hline Contributed years & 21.6 & $(8.9)$ & 20.9 & $(7.8)$ \\
\hline Current gross income & 77.5 & $(35.9)$ & 130.6 & $(61.9)$ \\
\hline Total private wealth (A) & 146.0 & $(171.1)$ & 235.7 & $(276.7)$ \\
\hline Financial wealth (A) & 46.7 & $(106.6)$ & 103.4 & $(210.3)$ \\
\hline Social sec. wealth (SSW) & 202.4 & $(52.0)$ & 216.1 & $(37.6)$ \\
\hline Pension wealth (PW) & 366.7 & $(227.5)$ & 709.7 & $(291.4)$ \\
\hline \multicolumn{5}{|l|}{ Non-employed } \\
\hline$\overline{\# \text { observations }}$ & 125 & & 50 & \\
\hline never had job & $7.2 \%$ & & $4.0 \%$ & \\
\hline Age & 57.9 & $(5.9)$ & 58.3 & (4.9) \\
\hline Contributed years ${ }^{(1)}$ & 29.6 & (11.7) & 30.1 & (8.6) \\
\hline Year stopped working $^{(1)}$ & 1989.3 & $(5.4)$ & 1990.9 & $(6.7)$ \\
\hline Current gross income & 48.0 & $(29.2)$ & 106.4 & $(36.8)$ \\
\hline Last gross labour income ${ }^{(1)}$ & 55.8 & $(25.7)$ & 132.9 & $(50.7)$ \\
\hline Total private wealth (A) & 184.4 & $(258.0)$ & 372.2 & $(219.2)$ \\
\hline Financial wealth (A) & 74.9 & $(146.9)$ & 167.3 & $(152.2)$ \\
\hline Social sec. wealth (SSW) & 263.2 & $(66.5)$ & 281.6 & $(37.6)$ \\
\hline Pension wealth (PW) & 149.1 & $(152.0)$ & 595.7 & (339.1) \\
\hline
\end{tabular}

Note: The number of contributed years is the number of years contributed to a pension fund. Current and last labour income are gross per year in 1,000 Dutch Guilders, while the wealth variables (A, SSW, PW) are net in 1,000 Dutch Guilders. Financial wealth is equal to total private wealth minus (own) housing wealth. Social security and pension wealth are actuarially discounted, see appendix C. Variables marked with ${ }^{(1)}$ are calculated only for men who had a job.

The previous paragraph shows that the income and pension rights of women will be neglected. This is of course unfortunate as this leads to measurement error in pension wealth and current income. But there are two data-driven reasons for this. The first reason is that divorced and widowed women often have pension rights through their (ex-)husband's employment history, and these pension rights are not observed in the data. The second reason is that in households with more than one person the response rate of women is low. However, there are reasons to believe that the measurement error due to neglecting women's pension 
rights is not that big. First, in the age-group under consideration female labour participation is quite low. Second, many employed women have relatively small pension rights because they work part-time. Since our data contains certain characteristics of all members of a household, we are able to learn something about the seriousness of this problem. Regarding couples in the representative panel, about 10 percent of women have a full-time job, and about 30 percent have a part-time job. Regarding couples in the high-income panel, about 30 percent of women have a full-time job, and another 30 percent have a part-time job. Therefore, although in the high-income panel the measurement error in pension wealth might not be that small, subsection 2.3 explains that a bias in equation (4) caused by measurement error will be towards zero. So the results of the empirical analysis can still be interpreted.

For the non-employed the current gross income is relatively high compared to the last gross labour income. The normal replacement rate for the benefit until official retirement at age 65 is 70 percent in case of unemployment and 80 percent in case of (full) disability. In case of early retirement it depends on the collective bargain of the industry or firm where the non-employed had been working. Only in case of a last gross labour income around or below the official minimum wage, which is possible due to part-time work, the replacement rate can be higher that 100 percent. In our data about 30 percent of the non-employed turn out to have a replacement rate of around or above 100 percent. As actually few of these earned wages around the minimum wage, this must be due to circumstances that we cannot control in our data. For example, the last earned wage might have been lower than the individual's normal wage, and therefore the benefit level was not completely based on the last wage.

The definition of private household wealth includes bank accounts, insurances, stocks, bonds, real estate, mortgages and debts. For an exact definition see appendix B. In the representative panel total private wealth is about double the gross yearly income for the employed, and about triple for the non-employed. A substantial part of wealth is invested in housing wealth; financial wealth is substantially lower. Furthermore, in the representative panel about 11 percent have negative wealth while in the high-income panel about 5 percent have negative wealth.

The value of social security wealth depends on age, marital status and the employment status of the partner. The value of pension wealth depends on the number of contributed years and the last earned gross labour income. For the exact calculation of both forms of retirement wealth see appendix C. Pension wealth is likely to be overestimated in table 2. In the CentER Savings Survey the number of contributed years is measured by asking the individuals to give 
the number of years they have been building up an entitlement to a pension. This is not necessarily equal to the number of years recognized by the pension fund. When an employee transferred his pension rights from one pension fund to another during his career (which often happens when an employee changes industry or firm), the number of recognized contributed years by the new pension fund can be lower than the number of contributed years accumulated until then. Although the CentER Savings Survey contains some information on these so-called 'pension-breaks', this information is not sufficient to take this explicitly into account. Furthermore, while about 25 percent of the supplementary pensions are a mixture of fixed amounts, average pay and last earned pay, our definition of pension wealth is based on the last earned wage. As wages typically increase with age, this also leads to an overestimation of pension wealth. Still, the informational content of the CentER Savings Survey on pensions is much larger than for other Dutch surveys, as they contain almost no data on pension rights. Again the following argument holds: In equation (4) a bias caused by measurement error will be towards zero, and therefore the results of the empirical analysis can still be interpreted.

Most studies dealing with pensions and savings are on dependent workers only. A reason for excluding self-employed is that their pension wealth is hard to measure. This is unfortunate as the self-employed have a large variability in mandatory pension wealth, and therefore are a substantial part of the evidence. In our data we observe the job characteristics of the current job for the employed, and of the last job for the non-employed. We decide to maintain two kinds of self-employed in our sample: the ones who have zero pension wealth (3.6 percent of the observations in the representative panel and 3.8 percent in the high-income panel), and the ones who have pension wealth in mandatory pension schemes which are specific for the occupation in which they are self-employed (3.8 percent in the representative panel and 2.7 percent in the high-income panel). In the empirical analysis we still decide to take the sample of dependent employees as the base case, as there is another problem: the definition of private wealth. Our definition does not include assets and debts in own businesses. We will use the self-employed only to do a sensitivity analysis.

Besides the data on pension rights and wealth, the CentER Savings Survey also contains information on attitudes and perceptions with respect to savings. The information we use concerns savings attitudes. The respondents are asked the following questions: 
We would like to ask you some questions on your personal opinion about savings. People have many different reasons for savings money for a short or for a long time. Please indicate your opinion about each statement mentioned on the screen below. Is it to you personally of much or little importance?

\section{Question 1:}

To supplement (in the future possibly lower) social security benefits (AOW)?

Possible answers: a scale from 1 (very unimportant) to 7 (very important).

\section{Question 2:}

To supplement my retirement pension, and to have some extra money when I am retired. Possible answers: a scale from 1 (very unimportant) to 7 (very important).

A normal finding from questions with this kind of scale is that respondents rarely use the extreme categories. This does not apply to these two questions; the answers are about evenly distributed over all seven possible answers.

\section{Empirical analysis}

In the empirical analysis we test for the effect of mandatory pensions on savings motives with respect to old age and on private household wealth. As the base case we take the sample excluding the currently self-employed, and we use the actuarially discounted social security and pension wealth. Next, we will do a sensitivity analysis by addressing issues like the method of discounting, early retirement and self-employment.

\section{$\underline{\text { Base case }}$}

The empirical results for the effect of mandatory pensions on savings motives and private household wealth are displayed in tables 3 and 4. Initially we also included a higher order term for age, marital status, and the number of grand-children in the analysis. These variables turned out to be insignificant, and we decided to exclude them. We also experimented with including the partner's labour market status in the analysis. The idea is to correct for the fact that we do not include the partner's income and pension wealth. Also this did not alter the results. For both employed and non-employed, pension wealth is related to current income. 
Thus for a proper identification of the effect of pension wealth correction for current net income is important.

Table 3 displays the results for the savings motives. For the representative panel we find that both social security and pension wealth have a significant negative impact on the importance of savings for old age. What we can conclude from this analysis is that the respondents take their pension rights into account when they answer such questions. Of course the question is whether this translates into actual behaviour. Furthermore, for the interpretation of this part of the analysis one must not forget that the analysis concerns savings motives of men. In couples, the woman tends to be younger than the man. Furthermore, the life expectancy of women is higher than for men. Therefore women will be more concerned about savings for old age. Due to the low response rate of the married and cohabiting women, this is unfortunately hard to analyse with our data.

The results on private household wealth turn out to be more mixed (see table 4). Social security and pension wealth have no significant impact. Using alternative definitions of private wealth by excluding housing wealth (which is non-liquid) and/or capital insurances (which are hard to measure) does not alter the results. On the other hand, for pension wealth the results are significantly different from full displacement - full displacement would be given by $\alpha_{3}=-100$ as we consider the variable $\mathrm{PW} / 100$.

For the calculation of pension wealth many assumptions are needed (see appendix C). Since one or more of these assumptions might be invalid, we also look at the independent effect of the variable that is most important for the calculation of pension wealth: the number of contributed years to a pension fund. Although this variable is not a perfect measure for pension wealth, it provides an inside into the impact of the mandatory pension rights on household wealth. For this variable we find no significant displacement effect for the representative panel, but for the high-income panel we do. Pension wealth itself did not have a significant impact for the high-income panel. This shows that the assumptions to calculate pension wealth are not very accurate. So we find some evidence that mandatory pension rights affect household wealth for high-income households.

Social security wealth is determined by variables that are also independently included in the analysis. So the impact of this variable is not well identified. In the following sensitivity analysis we concentrate on occupational pensions. Tables 5 and 6 display the sensitivity of the parameter for pension wealth in the savings motives regression, and the sensitivity of the parameters for the contributed years and pension wealth in private wealth regressions. 
Table 3: Savings motives regressions

Columns 1,3: How important are savings as a supplement to social security. (AOW)?

Columns 2,4: How important are savings as a supplement to your pension rights?

\begin{tabular}{|c|c|c|c|c|}
\hline \multirow[b]{2}{*}{ (\#obs.) } & \multicolumn{2}{|c|}{ Representative Panel } & \multicolumn{2}{|c|}{ High-Income Panel } \\
\hline & $\begin{array}{c}\text { suppl. } \\
\text { soc.sec. } \\
(358)\end{array}$ & $\begin{array}{c}\text { suppl. } \\
\text { pension } \\
(359) \\
\end{array}$ & $\begin{array}{c}\text { suppl. } \\
\text { soc.sec. } \\
(340)\end{array}$ & $\begin{array}{c}\text { suppl. } \\
\text { pension } \\
(342) \\
\end{array}$ \\
\hline constant & $-1.277 *$ & -0.957 & -0.769 & $-1.482 *$ \\
\hline & $(0.533)$ & $(0.528)$ & (0.611) & $(0.606)$ \\
\hline age man & $0.056^{*}$ & $0.063 *$ & -0.017 & -0.029 \\
\hline & $(0.024)$ & $(0.024)$ & $(0.092)$ & $(0.055)$ \\
\hline married & $\begin{array}{l}1.832 * \\
(0897)\end{array}$ & 2.479* & -0.246 & -1.431 \\
\hline age wife & $\begin{array}{l}(0.897) \\
-0.019\end{array}$ & $\begin{array}{l}(0.912) \\
-0.029 *\end{array}$ & $\begin{array}{c}(1.913) \\
0.012\end{array}$ & $\begin{array}{c}(1.923) \\
0.019\end{array}$ \\
\hline & $(0.014)$ & $(0.014)$ & $(0.026)$ & $(0.025)$ \\
\hline dummy child $<6$ & 0.078 & -0.097 & 0.202 & 0.330 \\
\hline & $(0.228)$ & $(0.227)$ & $(0.197)$ & $(0.198)$ \\
\hline \#children & -0.041 & -0.058 & -0.089 & -0.087 \\
\hline net income & $\begin{array}{c}(0.044) \\
0.016^{*}\end{array}$ & $\begin{array}{c}(0.044) \\
0.009\end{array}$ & $\begin{array}{c}(0.053) \\
0.017\end{array}$ & $\left.\begin{array}{c}(0.052) \\
0.015\end{array}\right)$ \\
\hline tiet incointe & $(0.008)$ & $(0.007)$ & $(0.010)$ & $(0.010)$ \\
\hline net inc ${ }^{2} / 1000$ & -0.083 & 0.072 & -0.052 & -0.045 \\
\hline SSW/100 & $\begin{array}{l}(0.073) \\
-0.658 *\end{array}$ & $\begin{array}{l}(0.064) \\
-0.666^{*}\end{array}$ & $\begin{array}{l}(0.037) \\
-0.114\end{array}$ & $\begin{array}{c}(0.036) \\
0.452\end{array}$ \\
\hline & $(0.287)$ & $(0.290)$ & $(0.624)$ & $(0.607)$ \\
\hline PW/100 & $\begin{array}{l}-0.169 * \\
(0.053)\end{array}$ & $\begin{array}{l}-0.196^{*} \\
(0.050)\end{array}$ & $\begin{array}{l}-0.099 * \\
(0.043)\end{array}$ & $\begin{array}{l}-0.088 \\
(0.041)\end{array}$ \\
\hline
\end{tabular}

Note: Income and wealth are in 1,000 Dutch Guilders. Estimation by ordered probit, standard errors in parentheses.

Table 4: Wealth regressions

Dependent variable: Private household wealth in 1000 Dutch Guilders

\begin{tabular}{|c|c|c|c|c|}
\hline \multirow{2}{*}{$\frac{\text { (\#obs.) }}{\text { constant }}$} & \multicolumn{2}{|c|}{$\begin{array}{c}\text { Representative Panel } \\
\text { (399) }\end{array}$} & \multicolumn{2}{|c|}{$\begin{array}{l}\text { High-Income Panel } \\
(351)\end{array}$} \\
\hline & $\begin{array}{c}-227.58^{*} \\
(96.98)\end{array}$ & $\begin{array}{c}-225.61 * \\
(8938)\end{array}$ & $-474.55^{*}$ & $\begin{array}{l}-314.13 * \\
(113.19)\end{array}$ \\
\hline age man & $\begin{array}{c}5.16 \\
(265)\end{array}$ & $\begin{array}{c}4.23 \\
(3.48)\end{array}$ & $\begin{array}{r}7.27 * \\
(3.37)\end{array}$ & $\begin{array}{l}-9.00 \\
(12.00)\end{array}$ \\
\hline married & -73.79 & -111.48 & $-286.63^{*}$ & -593.56 \\
\hline & (100.90) & (137.92) & $(135.42)$ & (395.31) \\
\hline age wife & $\begin{array}{c}2.13 \\
(156)\end{array}$ & $\begin{array}{c}2.63 \\
(230)\end{array}$ & 6.96* & $10.24 *$ \\
\hline dummy child $<6$ & $\begin{array}{l}(1.56) \\
15.34\end{array}$ & $\begin{array}{l}(2.30) \\
26.16\end{array}$ & $\begin{array}{r}(2.40) \\
175.59 *\end{array}$ & $\begin{array}{r}(4.80) \\
17899 *\end{array}$ \\
\hline & (29.88) & (29.94) & (58.39) & $(60.33)$ \\
\hline \#children & -6.89 & -7.81 & -0.23 & -2.06 \\
\hline net income & $\begin{array}{c}(9.04) \\
1.04\end{array}$ & $\begin{array}{l}(9.38) \\
-0.06\end{array}$ & $\begin{array}{c}(12.07) \\
2.72\end{array}$ & $\begin{array}{c}(12.17) \\
4.36\end{array}$ \\
\hline & $(1.10)$ & $(1.32)$ & $(1.42)$ & $(2.81)$ \\
\hline net inc $/ 1000$ & $\begin{array}{l}10.22 \\
(8.89)\end{array}$ & $\begin{array}{c}9.50 \\
(975)\end{array}$ & $\begin{array}{l}-7.67 \\
(5.69)\end{array}$ & $\begin{array}{c}-11.82 \\
(8.98)\end{array}$ \\
\hline contr. years & $\begin{array}{l}-1.53 \\
(1.43)\end{array}$ & & $\begin{array}{l}-6.16^{*} \\
(2.44)\end{array}$ & \\
\hline SSW/100 & & $\begin{array}{c}0.07 \\
(44.61)\end{array}$ & & $\begin{array}{c}145.01 \\
(138.13)\end{array}$ \\
\hline PW/100 & & $\begin{array}{l}10.87 \\
(9.53)\end{array}$ & & $\begin{array}{l}-10.82 \\
(10.60)\end{array}$ \\
\hline Adj- $R^{2}$ & 0.074 & 0.070 & 0.105 & 0.083 \\
\hline
\end{tabular}

Note: Income and wealth are in 1,000 Dutch Guilders. Estimation by ordinary least squares, Huber-Eicker-White standard errors in parentheses. Parameters marked with * are significant at a five percent significance level. 
Table 5: Sensitivity of parameter for pension wealth (PW/100)

Columns 1,3: How important are savings as a supplement to social security (AOW)?

Columns 2,4: How important are savings as a supplement to your pension rights?

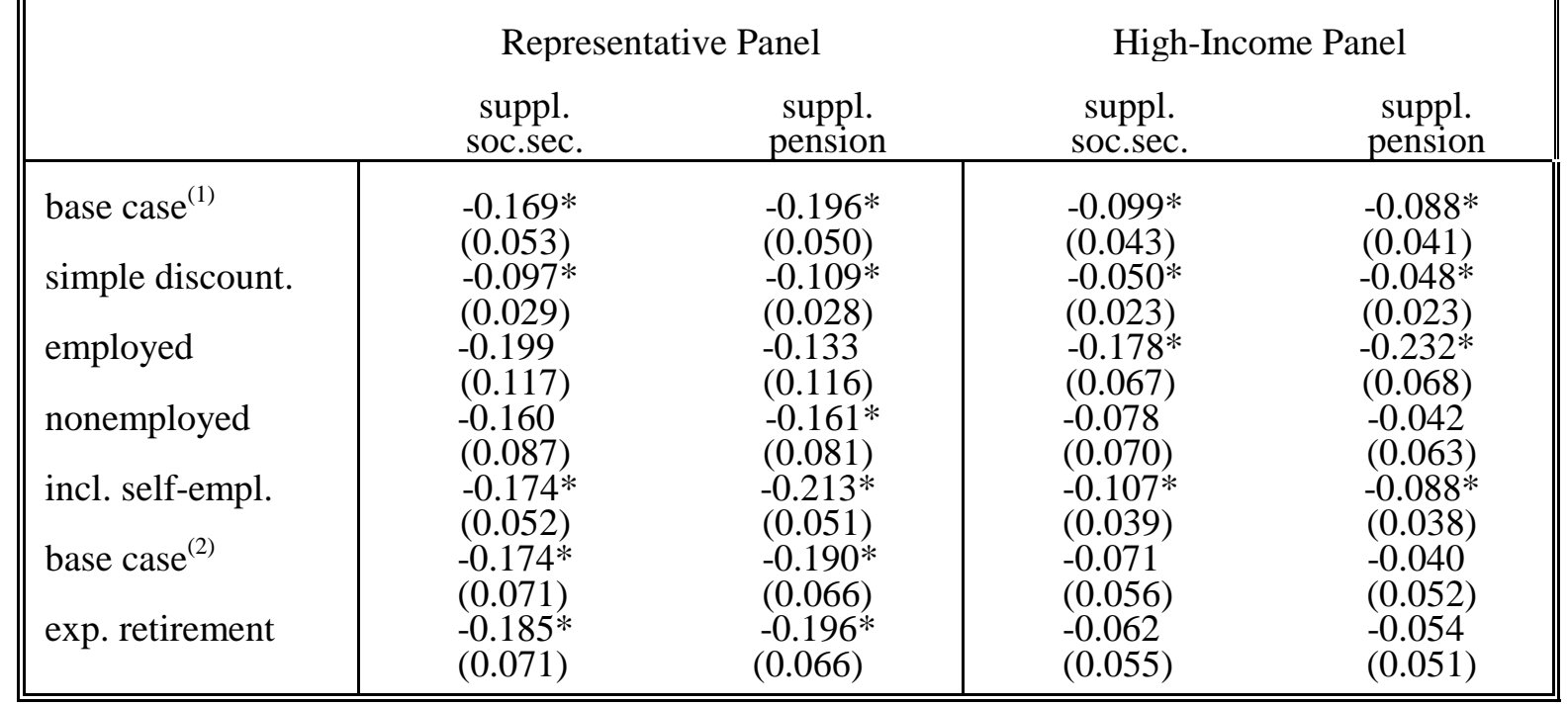

Note: Estimation by ordered probit, standard errors in parentheses. Parameters marked with $*$ are significant at a five percent significance level. The regressions additionally correct for individual characteristics and income (see table 3). The regressions include social security and pension wealth. Income and wealth are in 1,000 Dutch Guilders. ${ }^{(1)}$ Base case like in table 3 , followed by regressions with simple discounted social security and pension wealth, only employed, only non-employed and including selfemployed. ${ }^{(2)}$ Base case, but only for man over age 50, followed by regressions using the expected retirement age.

Table 6: Sensitivity of parameters for contributed years and pension wealth

\begin{tabular}{|c|c|c|c|c|}
\hline \multicolumn{5}{|c|}{ Dependent variable: Private household wealth in 1000 Dutch Guilders } \\
\hline & \multicolumn{2}{|c|}{ Representative Panel } & \multicolumn{2}{|c|}{ High-Income Panel } \\
\hline & $\begin{array}{l}\text { contr. } \\
\text { years }\end{array}$ & $\mathrm{PW} / 100$ & $\begin{array}{l}\text { contr. } \\
\text { years }\end{array}$ & $\mathrm{PW} / 100$ \\
\hline base case ${ }^{(1)}$ & -1.53 & 10.87 & $-6.16^{*}$ & -10.82 \\
\hline & (1.43) & $(9.53)$ & $(2.44)$ & (10.60) \\
\hline simple discount. & -1.53 & 5.24 & $-6.16^{*}$ & -6.90 \\
\hline & (1.43) & $(5.08)$ & $(2.44)$ & $(6.00)$ \\
\hline employed & -1.26 & -11.99 & -6.30 & -38.27 \\
\hline & (1.64) & (21.05) & $(3.51)$ & (25.73) \\
\hline nonemployed & -1.97 & $37.86^{*}$ & $-6.40^{*}$ & -8.44 \\
\hline & (2.13) & (17.48) & $(1.84)$ & $(8.41)$ \\
\hline incl. self-empl. & -2.22 & 4.96 & $-9.08^{*}$ & -28.84 \\
\hline base case ${ }^{(2)}$ & $\begin{array}{l}(1.32) \\
-2.62\end{array}$ & $\begin{array}{l}(9.79) \\
15.14\end{array}$ & $\begin{array}{l}(3.73) \\
-4.94 *\end{array}$ & $\begin{array}{c}(17.71) \\
-5.38\end{array}$ \\
\hline Dase Case & $(1.97)$ & (12.53) & $(2.34)$ & (9.89) \\
\hline exp. retirement & -2.62 & 14.87 & $-4.94 *$ & -1.89 \\
\hline & (1.97) & $(12.55)$ & $(2.34)$ & $(9.60)$ \\
\hline
\end{tabular}

Note: Estimation by ordinary least squares, Huber-Eicker-White standard errors in parentheses. Parameters marked with $*$ are significant at a five percent significance level. The regressions additionally correct for individual characteristics and current income, see table 4 . The regressions include either the number of contributed years, or social security and pension wealth. Income and wealth are in 1,000 Dutch Guilders. ${ }^{(1)}$ Base case like in table 4 , followed by regressions with simple discounted social security and pension wealth, only employed, only non-employed, including self-employed. ${ }^{(2)}$ Base case, but only for man over age 50 , followed by regressions using the expected retirement age. 


\section{Sensitivity analysis: Discounting}

Using actuarially discounted social security and pension wealth is correct only under certain assumptions. Bernheim (1987) claims that these assumptions are too strong and that simple discounting is better. We repeat the analysis with simple discounted social security and pension wealth, assuming that the individuals do not expect to get older than 100 years. Tables 5 and 6 confirm Bernheim's claim that discounting affects the size of the parameters. But the significance levels are unaffected.

\section{Sensitivity analysis: Early retirement}

Some studies correct for early retirement by using data on expected retirement age (see for instance Diamond and Hausman (1984) and Jappelli (1995)). Unfortunately in the CentER Savings Survey these data are observed for respondents over age 50 only. Using these data therefore leads to a substantial reduction in the number of observations (to 195 in the representative panel and 121 in the high-income panel). But we still use these data to do a sensitivity analysis. In the base case we assume that individuals over age 60 will retire with certain given probabilities. In base case ${ }^{(2)}$ we repeat the analysis for the sample of individuals over age 50 . The results stay more or less in line with base case ${ }^{(1)}$, although for the highincome panel we now get insignificant results for the savings motives. We repeat this analysis by using the expected retirement ages instead of the given early retirement probabilities. For both savings motives as well as wealth regressions the parameters and significance levels hardly change.

Another perspective on early retirement can be taken by splitting the sample into two parts: the employed and the non-employed. There are several reasons to do so. First, according to the life-cycle theory the non-employed (or at least the early retired) should have started to de-accumulate private wealth. Secondly, current income might have another meaning for the employed than for the non-employed: For the latter current (benefit) income indicates a higher last earned wage. Table 5 shows that for savings motives the signs of the parameters stay the same, but also that several parameters become insignificant. In the highincome panel, the impact for the employed becomes larger in absolute terms, although this impact is not significantly different from the impact for the non-employed. In the whole sensitivity analysis we get one remarkable result. For the non-employed in the representative panel pension wealth has a significant positive impact (see table 6). This is remarkable, as the number of contributed years stays insignificant and even has a negative sign. Therefore it is 
hard to give a reasonable interpretation for the significant positive impact of pension wealth. The other results for the effect on private wealth are more or less in line with the base case.

\section{$\underline{\text { Sensitivity analysis: Self-employment }}$}

Most studies in the literature deal with dependent employees. However, the self-employed are an interesting group because there is a large variation in their mandatory pension rights. A problem for this group is the definition of private wealth. In our definition we do not include assets and debts in own businesses. Since in the Netherlands many self-employed accumulate wealth in their own business to finance retirement, this could bias the results. Still we include them in our analysis. Table 6 shows that the parameters become more negative. However, the significance levels are unaffected.

\section{Conclusions}

The Dutch mandatory pension system consists of two parts: a public pay-as-you-go part that provides a minimum income to all Dutch inhabitants over age 64, and an occupation-specific capital-funded part that provides supplementary retirement income. In this paper we test for the effect of the mandatory pension provisions on discretionary household savings. According to the life-cycle model individuals should take their pension rights into account and adjust their private wealth accordingly. In the literature there is some controversy on this, since the measured displacement effects of mandatory pensions vary substantial over different studies.

The data for this study are drawn from the CentER Savings Survey, which contains rich information on household wealth, pension rights and savings attitudes. Besides studying the impact of mandatory pensions on private household wealth, we also study the impact on savings motives with respect to old age. We concentrate on households where a man aged between 40 and 65 is head or partner in the household. Pension rights and incomes of women are neglected, since for divorced and widowed women the pension rights through their (ex-) husband's employment history are not observed and since for couples the response rate of women is low. In the empirical analysis this and other measurement errors bias the displacement effects towards zero. The parameter estimates give underestimates for the real displacement effects.

A first conclusion of the empirical analysis is that the impact of social security is not well identified. In our empirical application it only depends on age, marital status and the partner's 
labour market status, which means that the variation in this variable is low. A second conclusion is that occupational pensions have a significant negative impact on savings motives with respect to old age. This can be explained by the fact that individuals take their pension rights into account when they answer such questions. Of course, the open question is whether this translates in actual behaviour. A third conclusion of the empirical analysis is that only for the highest-income-decile households we find evidence for a significant displacement effect of the occupational pensions in household wealth. Although the effect of pension wealth itself is insignificant, we find a significant negative impact of the number of contributed years to a pension fund.

The conclusions of this study are in strong contrast to the only other Dutch study using survey data by Alessie, Kapteyn and Klijn (1997). First, they find a significant negative impact of social security. This impact is identified on the basis of age, marital status and the partner's earnings. Because their preferred model specification includes a household-fixed effect, identification of the effect of social security wealth is mainly acquired by changes in the partner's earning over the different years. An open question is how good a source for identification this is. Second, the authors find an insignificant and sometimes even a significant positive impact of the occupational pensions. However, the Dutch Socio-Economic Panel, where their data are taken from, does not contain information on the number of years an individual contributed to a pension fund. Instead, this is imputed this by using the number of years that an individual was employed.

The fact that for the Netherlands the impact of social security is hard to identify on the basis of survey data gives that evidence on a macro-level is needed. Besseling (1994) finds that in the period from 1949 to 1992 Dutch national household savings did not react to the introduction and changes in the Dutch public, social security system. Survey data is more useful to identify the effect of occupational pensions. Evidence in this study, based on the CentER Savings Survey, gives that there is a displacement effect for high-income households. A reliable quantitative judgement on the size of the impact cannot be made. We can only conclude that there is no full displacement of the occupational pensions in the national household savings since no significant effect is found in the panel that is representative for the Dutch households. So occupational pensions push up Dutch national household savings, but the question whether this can explain the high gross national savings remains open. To get a more exact answer on the impact of the mandatory pension system on discretionary household savings, several more pieces of the puzzle are necessary. First, to identify the effect of social 
security an analysis on the macro-level is needed since it seems not identified on a microlevel. Secondly, to explain the high Dutch national savings an international comparison is needed. This could include the analysis to answer the first question. Thirdly, to identify the effect of occupational pensions on a micro-level an accurate model for the valuation of pension rights is needed.

\section{Literature}

Alessie, R.J.M., A. Kapteyn and F. Klijn (1997), Mandatory pensions and personal savings in the Netherlands, De Economist, 145, pp. 291-324.

Bernheim, B.D. (1987), The economic effects of social security, Journal of Public Economics, 33, pp. 273-304.

Besseling, P.J. (1994), Pensions, savings and the labour market in the Netherlands, Research Memorandum, 113, Centraal Planbureau, Den Haag.

Browning, M and A.M. Lusardi (1994), Household saving: micro theories and micro facts, Journal of Economic Literature, 34, pp. 1797-1855.

Davis, E. P. (1995), Pension funds, an international perspective, Clarendon Press, Oxford.

Deaton, A. (1992), Understanding consumption, Oxford University Press.

Diamond, P.A. and J.A. Hausman (1984), Individual retirement and savings behavior, Journal of Public Economics, 23, pp. 81-114.

Dicks-Mireaux, L. and M. King (1984), Pension wealth and household savings: tests of robustness, Journal of Public Economics, 23, pp. 115-139.

Feldstein, M. (1980), International differences in social security and saving, Journal of Public Economics, 12, pp. 225-244.

Feldstein, M. and A. Pellechio (1979), Social security and household wealth accumulation: new microeconometric evidence, Review of Economics and Statistics, 61, pp. 361-368.

Graham J. (1987), International differences in savings rates and the life cycle hypothesis, European Economic Review, 31, pp. 1509-1529.

Gale, W.C. (1995), The effect of pensions of wealth: a re-evaluation of theory and evidence, working paper, The Brooking Institution. 
Hoynes, H., M. Hurd and H. Chand (1997), Household wealth of the elderly under alternative imputation procedures, working paper, Berkeley.

Jappelli, T. (1995), Does social security reduce the accumulation of private wealth? Evidence from Italian survey data, Richerche Economiche, 49, pp. 1-31.

Kerkhofs, M., M. Lindeboom and J. Theeuwes (1998), Retirement, financial incentives and health, Tinbergen Institute Discussion Paper 98-111/3.

Kotlikoff, L.J. (1979), Testing the theory of social security and life cycle accumulation, American Economic Review, 69, pp. 396-410.

Little, R. and D.B. Rubin (1987), Statistical analysis with missing data, Wiley, New York.

Munnell, A.H. (1976), Private pensions and savings: new evidence, Journal of Political Economy, 84, pp. 1013-1032.

Nyhus, E.K. (1996), The VSB-CentER savings project: data collection, questionnaires and sampling procedurs, VSB-CentER progress report 42, Tilburg University.

OECD Employment Outlook, various years, OECD, Paris.

Overlevingstafels naar geslacht en leeftijd, (1997), Statistics Netherlands.

Pensioenkaart van Nederland, (1987), Pensioenkamer, The Hague.

Rust, J. and C. Phelan (1997), How social security and medicare affect retirement behaviour in a world of incomplete markets, Econometrica, 64 (4), pp. 781-831.

Witte vlekken op pensioengebied, (1997), Ministry of Social Affairs and Employment.

Yaari, M.E. (1965), Uncertain lifetime, life insurance and the theory of the consumer, Review of Economic Studies, 104, pp. 275-298. 


\section{Appendix A: The CentER Savings Survey}

The CentER Savings Survey was devised by researchers at CentER, Tilburg University. The sample consists of approximately 3000 households and is divided into two parts. The first part of approximately 2000 households is a random sample of Dutch households, whereas the second part of approximately 1000 households only draws from the high-income households (which are defined as the households whose income is larger than 105,000 Dutch Guilders in 1991). The first wave started in 1993, and subsequent waves are collected at an annual frequency. Households are interviewed by means of a computer questionnaire, which is administrated through modems (CAPAR: Computer Assisted Panel Research). For more information on this method of questioning and on the consequences for the data being representative see Nyhus (1996).

The CentER Savings Survey is organized in five modules: Household and Work (1), Income (2), Accommodation and Mortgages (3), Wealth (4) and Economic Psychology (5). The most important data for this paper are found in module 1 (individual characteristics) and modules 3 and 4 (individual wealth holdings). Since not all participants in the panel answered the questions on all modules, a merging of the modules on an individual level gives a reduction in the number of observations. The consequences for the number of observations are given in table A.2. Before turning to this issue, an extra complication has to be discussed: the timing of the panel.

Table A.1: Waves and observed modules

\begin{tabular}{||c|c|ccccc||}
\hline \hline \multicolumn{1}{|c}{ Year } & Running period & Work & Income & Acc. & Wealth & Psych. \\
\hline wave 1993 & Dec 93 - Apr 94 & X & X & X & X & X \\
wave 1994 & May 94 - Oct 94 & - & X & - & X & - \\
wave 1995 & May 95 - Oct 95 & X & X & X & X & X \\
\hline \hline
\end{tabular}

The waves of the CentER Savings Survey run yearly over the period from May to October. Due to delays the first wave runs over the period December 1993 to April 1994. The second wave (and all later waves) started in May. To prevent the participants from answering the same questions within such a small time period, several modules were not used in the second wave. However, these modules were used for the new participants in the panel. To get an overview of the modules contained in the different waves, see table A.1. To use these data as a panel, we use wave 1994 as the first wave in the analysis. The problem of missing data 
due to unobserved modules will be solved by imputing data from wave 1993. As there are only a few months between these two waves, this seems a reasonable solution. The data on income and wealth always refer to the year 1994. The main point to remember is that the first wave in the analysis contains the participants of wave 1993 and the new participants of wave 1994. Outside this appendix these two pooled waves will be referred to as wave 94.

Now we return to the issue of the merging of the modules. The first selection criterion is to select all men who are head or partner in their household. For the first wave this results in $1442+561=2003$ observations in the representative panel and $898+22=920$ observations in the high-income panel. The second step is to merge the married men to their spouses. This means that married men whose spouses are not observed are deleted from the data. This is only a rather small reduction in the number of observations. More serious is the third step: merging the wealth data. For the first wave of the representative panel this reduces the number of observations by about 27 percent, and in the high-income panel by about 21 percent. Since the high-income panel was especially devised for studying asset holdings, so that the participants were better informed about the kind of questions, the lower non-response rate in the highincome panel does not come as a surprise. The fourth step again gives a large reduction in the number of observations: about 39 percent in the representative panel and about 22 percent in the high-income panel. Because income is used as a question in the next year's wave, this is mainly due to panel attrition.

Table A.2: Selection criteria and number of observations

\begin{tabular}{||l|cc|cc||}
\hline \multicolumn{2}{||c}{} & \multicolumn{2}{c}{ Representative Panel } & \multicolumn{2}{c||}{ High-Income Panel } \\
Selection criteria & 1993 & 1994 & 1993 & 1994 \\
\hline Step 1: Men & 1442 & 561 & 898 & 22 \\
Step 2: +Spouse & 1413 & 532 & 871 & 20 \\
Step 3: +Wealth & 1058 & 371 & 697 & 9 \\
Step 4: +Income & 621 & 244 & 550 & 2 \\
Step 5: +Other & 578 & 228 & 529 & 2 \\
\hline
\end{tabular}

Note: Step 1 selects all men who are head or partner, step 2 merges the married men to their spouses, step 3 merges the wealth data of both the men and their spouses, step 4 merges the income data of the men, and step 5 adds more criteria (concerning item non-response). In case of a couple in which the man is mostly involved with the financial administration of the household and the wealth of the spouse is unobserved, the wealth holdings of the spouse are ignored. 


\section{Appendix B: Measurement of income and wealth}

The CentER Savings Survey is especially designed to study individual and household savings behaviour. This means that a large effort was made in order to measure income and wealth as accurate as possible. This appendix discusses in more detail the measurement of these variables and how we deal with item non-response.

\section{B.1: Income}

In the CentER Savings Survey gross income of a certain year is observed in the wave of the next year on the basis of gross income reported to the tax-authorities. This way the participants can be much more sure on their gross income and do not have to estimate their gross income of the current year. A disadvantage is that this leads to missing data due panel attrition. For wave 94 (complete sample; table A.2, step 4) about 27 and 16 percent of the respondents in the representative and the high-income panel are not observed in the next year. Besides panel attrition, missing values on certain income categories lead to missing data on income. This kind of missing income occurs for 12 and 6 percent in the representative and the high-income panel. Adding these two kinds of missing income, we get missing income for about 39 and 22 percent of the representative panel and high-income panel.

On the basis of the rich data, net income is calculated accurately in the CentER Savings Survey. This is important, as the model of subsection 2.2 is defined in terms of net income. The calculated net income takes into account tax deductibles like interest payments on mortgages. However, these calculated net incomes are not sufficient for the empirical analysis. We also need to calculate the future net retirement incomes. To be able to calculate these from the gross retirement incomes which are determined on the basis of the number of contributed years and the last earned gross wages, we have to impute the tax system for households with a head of household over age 65 (tax-payers aged over 65 do not contribute to the social security system and therefore face lower tax-rates). Applying the exact tax-rules for the future incomes would be too time-consuming. We therefore decide to approach the tax-system by using the data on households with a head of household over age 65 . We assume that the men in our group of interest (aged 40-65) believe that the tax-rules will not change over time. See appendix $\mathrm{C}$ for more details. 


\section{B.2: Wealth}

In the CentER Savings Survey a large effort was made to measure the value of assets as accurate as possible. In order to prevent misunderstandings the respondents first get a definition of the specific asset under consideration. The question posed is how many assets of each kind they own, and what the financial value of each asset is. In total, 38 assets are considered. Of these we include the following in our definition of private wealth: checking accounts (1), employer sponsored savings plans (2), savings accounts (3), deposit books (4), deposit accounts (5), savings certificates (6), single-premium annuities (7), endowment insurances (8), combined annuity and life insurances (9), pension schemes, not partly paid by the employer (10), growth funds (11), mutual funds (12), mortgage bonds (13), company shares (14), all kinds of options (15-18), real estate not used for own housing (19H), money lent to family/friends $(24)$, other savings $(25)$, own house $(26 \mathrm{H})$, second house $(27 \mathrm{H})$. On the debt side we include: mortgage on real estate (19M), mortgage on own house (26M), mortgage on second house (27M), private loans (D1), extended credit (D2), hire-purchase contracts (D3), mail-order debt (D4), loans from family/friends (D5), study loans (D6), credit card debts (D7), debts not mentioned before (D8). Also observed in our data are: cars (20), motorbikes (21), boats (22) and caravans (23). We decide not to include them in private household wealth since they are durable consumption goods.

In survey data item non-response is a known problem. Earlier experience shows that this problem is more serious concerning the collection of wealth data than concerning more traditional kinds of data. Therefore we follow the methodology used in the Health and Retirement Survey (HRS) and Asset and Health Dynamics (AHEAD) survey. A question about the value of a certain asset was asked according to the following strategy: First, the respondent is asked to give the exact value in Dutch Guilders. If he/she declines to answer this open-ended question, the respondent is asked to give the financial value within certain brackets. The data resulting from the second question is less accurate, but at least it gives useful information on the value of the asset. For the HRS and AHEAD it was observed that this methodology leads to a substantially lower item non-response.

The followed method for retrieving the asset data leads to two measurement issues. First, one has to deal with the bracketed data. The best way would be to take it explicitly into account in the analysis. But obviously this complicates the analysis substantially, so this method is seldom used. The common solution is to use imputation for the bracketed answers. 
Several sophisticated imputation methods have been developed (see Little and Rubin (1987) for an overview). In the case of the HRS and AHEAD data often extended versions of the socalled Hot Deck procedure were used (see for instance Hoynes, Hurd and Chand (1997)). A difference with the CentER Savings Survey is that the HRS and AHEAD data contain fewer groups of assets. Using a sophisticated method for imputation in the CentER Savings Survey would be very time-consuming. Therefore, the simplest method is used: In the case of values in brackets, the centre value of the bracket was imputed. Generally, there are 14 brackets. This should give a reasonable approximation, except for the last bracket where no centre value exists. This leads to the second measurement issue: missing and censored values. In both the representative and the high-income panel this occurs for about 25 percent of the observations for at least one asset. In this paper we treat this as measurement error.

\section{Appendix C: Social security and pension wealth}

For social security and pension wealth, we calculate both the simple and actuarially discounted sum of the future net incomes from social security and pensions. To do this, several assumptions on the expectations of the individuals are needed:

1: Benefit rules and levels remain the same (except for inflation correction);

2: Tax rules remain the same (except for inflation correction);

3: Inflation rate and nominal net benefit growth are one percent $\left(\mathrm{r}^{\mathrm{i}}=\mathrm{r}^{\mathrm{b}}=0.01\right)$, nominal net wage growth is two percent $\left(\mathrm{r}^{\mathrm{w}}=0.02\right)$ and real interest rate is three percent $(\mathrm{r}=0.03)$;

4: Unemployment, disability and early retirement are absorbing states;

5: Early retirement and disability happen with given probabilities (so no behaviour);

6: Family status does not change (except through death);

7: Individual survival probabilities within families are independent.

The public, social security part of the Dutch pension system basically gives a flat benefit that is derived from the official net minimum wage. For instance, for a couple with no other labour income the net benefit level is equal to the net minimum wage, while for a couple with other labour income the net benefit level is between 70 and 100 percent of the net minimum wage. For a single person the net benefit level is 70 percent of the net minimum wage. Concerning couples, we do not observe the income of the partner. We assume that a couple with an employed partner receives the minimum benefit level: 70 percent. Furthermore, if the 
husband dies, and the spouse did not reach age 65 yet, she will receive income through the Law on Widows (AWW). In practice, the social security benefits are paid in gross terms and are subject to taxes. The gross benefit levels are derived from the net benefit levels for households with certain 'standard' characteristics (and these calculations are done by the Ministry of Social Affairs and Employment). Because in our data the net labour incomes are measured taking by taking into account tax deductibles, we do this also for future retirement incomes. As applying the exact tax-rules would be too time-consuming, we approach the tax system by using the data in CentER Savings Survey on households with a head of household over age 65. As these data contain both gross and net retirement incomes, we are able to map the future gross retirement incomes into the future net retirement incomes.

To calculate the actuarially discounted social security, we use the Overlevingstafels naar Geslacht en Leeftijd (the 'Survival tables by Sex and Age,' 1997). So the social security wealth for singles (C.1s) and couples (C.1m) is defined as:

(C.1a) $\mathrm{SSW}=\Sigma_{\mathrm{s}=65, \infty}\left(\left(1+\mathrm{r}^{\mathrm{b}}\right) /(1+\mathrm{r})\right)^{\mathrm{s}-\mathrm{h} \_ \text {age }} \mathrm{ph}_{\mathrm{h} \_ \text {age, } \mathrm{s}} \mathrm{nAOW}($ single, -$)$

$$
\begin{aligned}
& \text { (C.1b) } \mathrm{SSW}=\Sigma_{\mathrm{s}=65, \infty}\left(\left(1+\mathrm{r}^{\mathrm{b}}\right) /(1+\mathrm{r})\right)^{\mathrm{s} \text {-hage }}\left[\mathrm{ph}_{\mathrm{h} \_ \text {age,s }} \mathrm{pp} \mathrm{p} \_ \text {age,s }_{\mathrm{n}} \mathrm{nAOW}(\text { married,p_emp })\right. \\
& +\mathrm{ph}_{\mathrm{h} \_ \text {age,s }}\left(1-\mathrm{pp}_{\mathrm{p} \_ \text {age, }}\right) \mathrm{nAOW}(\text { single,-) } \\
& +\left(1-\mathrm{ph}_{\mathrm{h} \_a g e, s}\right) \mathrm{pp}_{\mathrm{p} \_ \text {age,s }} \mathrm{nAWW} \mathrm{I}\left(\mathrm{p} \_ \text {age }<65\right) \\
& \left.+\left(1-\mathrm{ph}_{\mathrm{h} \_ \text {age, }}\right) \mathrm{pp}_{\mathrm{p} \_ \text {age,s }} \mathrm{nAOW}(\mathrm{s}, 0) \mathrm{I}\left(\mathrm{p} \_ \text {age } \geq 65\right)\right]
\end{aligned}
$$

$\begin{array}{ll}\mathrm{y}^{\mathrm{n}}\left(\mathrm{y}^{\mathrm{g}}\right) & =\text { tax function, maps gross income } \mathrm{y}^{\mathrm{g}} \text { into net income } \mathrm{y}^{\mathrm{n}} \\ \mathrm{gAOW}\left(\mathrm{m} \_\mathrm{s}, \mathrm{p} \_\mathrm{e} p\right) & =\text { gross social security income } \\ \mathrm{gAWW} & =\text { gross income through the Law on Widows } \\ \mathrm{nAOW}\left(\mathrm{m} \_\mathrm{s}, \mathrm{p} \_\mathrm{emp}\right) & =\mathrm{y}^{\mathrm{n}}\left(\mathrm{gAOW}\left(\mathrm{m} \_\mathrm{s}, \mathrm{p} \_\mathrm{emp}\right)\right) \\ \mathrm{nAWW} & =\mathrm{y}^{\mathrm{n}}(\mathrm{gAWW}) \\ \mathrm{m} \_\mathrm{s} & =\text { marital status } \\ \mathrm{h} \_ \text {age } & =\text { age man } \\ \text { p_age } & =\text { age partner } \\ \mathrm{p} \_\mathrm{emp} & =\text { employment status partner } \\ \mathrm{I}(\mathrm{x}) & =\text { indicator function, equal to one if } \mathrm{x} \text { is true } \\ \mathrm{ph}_{\mathrm{t}, \mathrm{s}} & =\text { probability husband lives at time } \mathrm{s} \text {, given alive time } \mathrm{t} \\ \mathrm{pp}_{\mathrm{t}, \mathrm{s}} & =\text { probability partner (wife) lives at time } \mathrm{s} \text {, given alive time } \mathrm{t}\end{array}$


The private part of the Dutch pension system is capital-funded and consist of several industry and firm specific pension funds. But for almost all pension funds the following rule holds: If an individual works 40 years for the same employer, the gross pension benefit is equal to 70 percent of the last earned gross wage. The accrual rate of these pension funds is therefore equal to $0.0175(=0.70 / 40)$. Since individuals over age 65 do not pay social security premia, this percentage becomes about 90 percent at an after tax base. Define:

(C.2) $\operatorname{gPENS}=\max \left(0.0175^{*} \min \left(\mathrm{n}^{\mathrm{p}}, 40\right) *\left(\mathrm{w}^{-1}\right.\right.$-franchise $\left.), 0\right)$

$$
\begin{array}{ll}
\operatorname{gPENS} & =\text { gross supplementary pension benefit } \\
\mathrm{n}^{\mathrm{p}} & =\text { number of contributed years (to a pension fund) } \\
\mathrm{w}^{-1} & =\text { last earned gross wage in Dutch guilders per year } \\
\text { franchise } & =(10 / 7) * \mathrm{gAOW}(\text { married,nonemployed })
\end{array}
$$

All former employees who contributed to a pension fund get this gross pension additional to their social security benefit, regardless of marital status. Widows of former employees get 70 percent of their husbands gross pension rights. The net supplementary pension benefit is calculated by using the tax rules determined on the basis of data on households with a head of household over age 65 . The net pension wealth for singles (C.3a) and couples (C.3b):

(C.3a) $\quad \mathrm{PW}=(1 /(1+\mathrm{r}))^{65-\mathrm{h} \_ \text {age }} \sum_{\mathrm{s}=65, \infty}\left(\left(1+\mathrm{r}^{\mathrm{w}}\right) /(1+\mathrm{r})\right)^{\mathrm{s}-65} \mathrm{ph}_{\mathrm{h} \_ \text {age, } \mathrm{s}} \mathrm{nPENS}($ single, -$)$

(C.3b) $\mathrm{PW}=(1 /(1+\mathrm{r}))^{65-\mathrm{h} \_ \text {age }} \sum_{\mathrm{s}=65, \infty}\left(\left(1+\mathrm{r}^{\mathrm{w}}\right) /(1+\mathrm{r})\right)^{\mathrm{s}-65}\left[\mathrm{ph}_{\mathrm{h} \_ \text {age,s }} \mathrm{pp} \mathrm{p}_{\mathrm{p} \_ \text {age,s }} \mathrm{nPENS}\left(\operatorname{married}, \mathrm{p} \_\mathrm{emp}\right)\right.$

$$
\begin{aligned}
& +\mathrm{ph}_{\mathrm{h} \_ \text {age }, \mathrm{s}}\left(1-\mathrm{pp}_{\mathrm{p} \_ \text {age }, \mathrm{s}}\right) \operatorname{nPENS}(\text { single, }-) \\
& \left.+\left(1-\mathrm{ph}_{\mathrm{h} \_ \text {age }, \mathrm{s}}\right) \mathrm{pp}_{\mathrm{p} \_ \text {age }, \mathrm{s}} \mathrm{nPENSw}(\operatorname{single},-) \mathrm{I}\left(\mathrm{p} \_ \text {age }>65\right)\right]
\end{aligned}
$$

To calculate the net pension income, we assume that individuals consider their social security income as a base income, and supplementary pensions as an additional income (see also equations (3a) and (3b) in subsection 2.2).

(C.4a) nPENS(m_s,p_emp) $=\mathrm{y}^{\mathrm{n}}\left(\mathrm{gAOW}\left(\mathrm{m} \_\mathrm{s}, \mathrm{p} \_\mathrm{emp}\right)+\mathrm{gPENS}\right)-\mathrm{y}^{\mathrm{n}}\left(\mathrm{gAOW}\left(\mathrm{m} \_\mathrm{s}, \mathrm{p} \_\mathrm{emp}\right)\right)$

(C.4b) nPENSw(single, -$)=y^{\mathrm{n}}\left(\right.$ gAOW $($ single,-$)+0.7^{*}$ gPENS $)-y^{\mathrm{n}}(\mathrm{gAOW}($ single, -$))$ 